\title{
Why a Canadian Musicologist Would Catalogue One Thousand Mexican Music Manuscripts
}

\author{
John G. Lazos
}

\begin{abstract}
It has been fifteen years since I started visiting religious and secular music archives across Mexico. From the beginning, one issue quickly became clear: unless cataloguing was done, the manuscripts might disappear from our memories, along with our understanding of four centuries of music practice. My work focussed specifically on the nineteenth century, an era of music practice that was almost unknown to us. As my research began, I had to request permission to enter archives, apply for financial support, then travel to organize and digitize manuscripts and to produce the catalogues. During part of this process, and to give my work a wider exposure, I contacted RISM. At that moment, their database had only 48 entries representing Mexico. Even now, with more than a thousand titles, there remains still so much music to document.

This article highlights my fifteen years of work, and in particular, the last two catalogues that I have produced: "José Antonio Gómez y Olguín (1805-1876) y su Catálogo musical: Un acercamiento a la práctica musical del México decimonónico [English introduction included]," FONCA (México, 2016); and "Catálogo del Acervo Musical del Colegio de Vizcaínas (AMCV): La memoria sonora de los colegios femeninos en México entre los siglos XVI-XIX [Introducción en español y en inglés]," FONCA (México, 2019). These catalogues follow my personal ideas for improving accessibility and our understanding of our musical past. They are both online and in pdf format, and in addition to providing the same information found in RISM's database, they include an image for each work to provide identity and depth.

While access to and study of musical archives is still limited in Mexico, we are starting to have some first-hand knowledge of this vast and rich music tradition.
\end{abstract}

John Lazos (jlazos11@hotmail.com) is an independent scholar. His research focuses on the search, rescue, organization and study of Mexican music from the nineteenth century. He collaborates with the International Repertory of Musical Sources (RISM), where he has uploaded nearly one thousand musical manuscripts to its database. Learn more about his contributions here: http://www.rism.info/index.php?id=724. The author wishes to thank Karen Zacy Benner for the revision and editing of this article. He would also like to thank the readers and editors of CAML Review for their comments and suggestions.

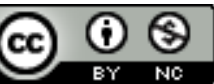

This work is licensed under a Creative Commons Attribution-NonCommercial 4.0 International License. 


\title{
Pourquoi un musicologue canadien voudrait cataloguer mille manuscrits musicaux mexicains
}

\author{
John G. Lazos
}

\section{Résume}

Cela fait quinze ans que j'ai commencé à visiter les archives de musique religieuse et profane à travers le Mexique. Dès le début, un problème est rapidement devenu clair : à moins que le catalogage ne soit fait, les manuscrits pourraient disparaître de nos mémoires, avec notre compréhension de quatre siècles de pratique musicale. Mon travail s'est concentré spécifiquement sur le XIXe siècle, un domaine où la pratique musicale nous était presque inconnue. Au début de mes recherches, j'ai dû demander l'autorisation d'entrer dans les archives, demander un soutien financier, puis me déplacer pour organiser et numériser les manuscrits et produire les catalogues. Pendant une partie de ce processus, et pour donner une plus grande visibilité à mon travail, j'ai contacté RISM. À ce moment-là, leur base de données ne contenait que 48 entrées représentant le Mexique. Même maintenant, avec plus d'un millier de titres, il reste encore tant de musique à documenter.

Cet article met en lumière mes quinze ans de travail et en particulier les deux derniers catalogues que j'ai produits: «José Antonio Gómez y Olguín (1805-1876) y su Catálogo musical: Un acercamiento a la práctica musical del México decimonónico [introduction en anglais inclus] », FONCA (México, 2016); et «Catálogo del Acervo Musical del Colegio de Vizcaínas (AMCV): La memoria sonora de los colegios femeninos en México entre los siglos XVI-XIX [Introducción en español y en inglés]", FONCA (México, 2019). Ces catalogues suivent mes idées personnelles pour améliorer l'accessibilité et notre compréhension de notre passé musical. Ils sont à la fois en ligne et au format pdf, et en plus de fournir les mêmes informations que celles trouvées dans la base de données RISM, ils incluent une image pour chaque œuvre, pour fournir une identité et une profondeur.

Bien que l'accès aux archives musicales et leur étude soient encore limités au Mexique, nous commençons à avoir une connaissance de première main de cette vaste et riche tradition musicale.

John Lazos (jlazos11@hotmail.com) est chercheur indépendant. Ses recherches s'est concentré sur la recherche, l'organisation et l'étude de la musique mexicaine du dix-neuvième siècle, une musique suit doit être sauvgarder. Il collabore avec le Répertoire international des sources musicale (RISM), où il a téléchargé près d'un millier de manuscrits musicaux dans sa base de données. Veuillez trouver ses contributions en ligne : http://www.rism.info/index.php?id=724. L'auteur tient à remercier Karen Zacy Benner pour la révision et l'édition de cet article. Il tient également à remercier de la Revue de l'ACBM pour leurs commentaires et suggestions.

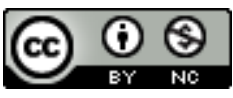

This work is licensed under a Creative Commons Attribution-NonCommercial 4.0 International License. 
The account and relics that serve as the historian's

starting point form the data which have survived

into the present and which the historian seeks to explain by making an assumption about past events. And it is these conceptualized events, and not the given materials, that represent the historical facts he seeks. Carl Dahlhaus, Foundations of Music History

We assume that musical works appear because somewhere, someone, sometime ago decided to write, arrange, and copy them for the sake of performance at a given time. If a source is lost or absent, then performance and study can no longer take place. If this is the case for a body of work, by extension, a musical practice vanishes and is forgotten, unless the sources can be traced back once again. The objective of rediscovery for a performance, for example, is to produce an edition as close as possible to the original work. Therefore, the need to preserve our documented memory becomes an urgent matter.

I have not focussed on research and cataloguing in Canada, since most music here is well ordered and safely archived. It seems to take an obsessive mind to develop an organizational system for cultural artefacts and to make their organization intelligible. I began my own obsessive cataloguing journey in 2005, when I asked myself, why not try to catalogue music from Mexico, particularly in the Cathedral of San Cristobal de Las Casas, in Chiapas, a colonial city I have visited many times since my childhood and even lived nearby. This is also where I found the manuscript that formed the basis for my doctoral studies.

Before I outline the work that I have done, let me briefly describe some important facts about music of the church in Mexico from the arrival of Spanish music in the early sixteenth century up to the end of the nineteenth century, and how this history has affected the state of music manuscripts.

When the Spanish Crown realized the extent of their vast and unknown territory, which had been discovered through serendipity, it turned to the religious orders for help. In Mexico, known then as New Spain, the Franciscans were the first to arrive in 1524, followed shortly after by the Dominicans in $1526,{ }^{1}$ and the Augustinians in 1532 . Some years later, a fourth noteworthy order, the Sociedad de Jesús, the Jesuits, came in $1572 .{ }^{2}$ These religious orders established the basis for Catholic

\footnotetext{
1 "The Dominicans, or preaching priests, reached New Spain in 1526. In addition to their work as missionaries, they attached great importance to intellectual work because the structure and constitution of their Order required it." Mauricio Beuchot, The History of Philosophy in Colonial Mexico, tr. Elizabeth Millán (Washington, DC: Catholic University of America Press, 1998): 63.

${ }^{2}$ The Society of Jesus is an important factor for the independence movement during the early nineteenth century. See Robert Murrell Stevenson, Music in Mexico. A Historical Survey (New York: Thomas Y. Crowell Company, 1952): 52-62.
} 
practice in New Spain, given that religious "conversion was an integral part of conquest, as the Spanish colonizers superimposed their community, both physically and socially, upon the native population." ${ }^{3}$

In the end, this imposition of sacred values was part of a profound cultural domination. The religious orders understood the significance of music as a tool for what became the long, difficult and painful process of conversion. It was through the daily practice of plainchant and polyphonic music of the church liturgy that the evangelization was enforced. Cultures from both sides of the Atlantic were, in a matter of decades, living and melding together. The result is called, using a light euphemism, the mestizo Mexico.

Once settled, the church and its orders never left. Whatever its size, every Hispano-American town or metropolis is based on the same plan, dominated by a central area: on one side of the main square is the religious temple, accompanied by the governmental office on the other side, while the rest consists of businesses. These are not accidental placements; this prescribed plan was meant to be the origin and end point of all ceremonies. The establishments around the central plaza were designed to rule and govern as the spiritual, administrative, and economic powers. By extension, this placement configured the social and cultural life, including music, of the Mexican cities of New Spain.

This music machine proved quite successful even decades after Mexico became independent in 1821. No longer under Spanish domination, the newly independent Hispano-Americans, like many other peoples, found their musical inspiration in Italian opera. In Mexico City, the single original theatre was speedily joined by others. They competed for audiences avid to see new productions and to be seen. ${ }^{4}$ Musicians trained in the church found their way into a new secular society as teachers. Pioneers in the field, they opened music schools, organized concerts, edited and published music and music methods, and of course, performed in the theatres. These musicians laid the foundation for music practices still active today. And yet, in the written history of Mexican music, these pioneer musicians have been barely mentioned. We will return to this matter later in this essay.

\footnotetext{
${ }^{3}$ Derek Davis, Church-State Relations and Religious Liberty in Mexico: Historical and Contemporary Perspectives (Waco, Tex: J.M. Dawson Institute of Church-State Studies, Baylor University, 2002): 4.

${ }^{4}$ The theatre in Mexico City became an extension of the structural society during the independent period. In fact, "the authorities used the theatre to reinforce the role of the state, as civil celebrations would generally finish with a play setting [...] the theatre was for entertainment and also a space to socialize." Unless otherwise stated, the translations are mine. Delgado, Susana; cord. Anne Staples, "Entre murmullos y penurias: el teatro novohispano del siglo XIX," Historia de la vida cotidiana en México. T. 4, Bienes y vivencias, el siglo XIX, (México, D.F.: El Colegio de México, Fondo de Cultura Económica, 2005): 390.
} 
The locations of Mexico's legacy of nineteenth-century ecclesiastic music are spread throughout a complex geographic area. ${ }^{5}$ This music is divided between the ecclesiastic and secular archives or storage systems (as the case may be) in cathedrals, basilicas, convents, colleges, and parish churches, as well in the conservatories, libraries, museums, and private collections. As a result of this distribution of a national treasure, it is not possible to have an accurate estimation of how many original music manuscripts and copies actually exist or remain to be catalogued. Thousands of documents have gone unnoticed because basic organization is still pending. Apart from the massive choir books, which were elaborate and costly to produce, music collections were based mainly on manuscripts, which included music that was composed, studied, copied, and arranged. Scattered among these exemplars, on rough locally made paper, are original works by composers from Europe and Mexico. The music and practice of these musicians and composers is remembered only through these documents.

Each manuscript is a unique document. Even if two copies of the same work exist in different archives, they are transformed into different iterations through different local practices. Unfortunately, these various copies are lost if the music is not catalogued and stored properly. It is not surprising to find copies of important works abandoned at the top of bookshelves, hidden inside unidentified boxes, piled up and covered in dust, or locked away in drawers. If a manuscript is lost by accident or negligence, nothing can be done to recuperate that music, its past practice, or future potential.

When looking for an original subject for my doctoral studies in Montreal, I encountered my first music collection in a most unexpected place. Through a project called MUSICAT, Music of the Cathedrals, ${ }^{6}$ I learned there was music at the Archive of the Cathedral of San Cristóbal de Las Casas in Chiapas. Other researchers had attempted to view the manuscripts in this archive but were not able to obtain permission. Maybe because I was persuasive or desperate, after waiting at the archive and for hours outside his house, I was able to meet with and convince its director, Andrés Aubry (1927-2007), to consider my request. With great conviction I told him I could organize, identify, digitalize, label, and create a music catalogue. However, I forgot to mention that I had never done any of these tasks before. Aubry allowed me to set up a table in the archive and to start work. ${ }^{7}$

I was convinced that I had an interesting project in hand. Being accepted at the Université de Montréal musicology program gave me the freedom to concentrate on a single manuscript and its composer. I chose Invitatorio, Himno y 8 Responsorios by José Antonio Gómez y Olguín (1805-1876),

\footnotetext{
${ }^{5}$ In 1821, when Mexico became independent, it covered twice the territory it does today.

${ }^{6}$ See MUSICAT, http://musicat.unam.mx/.

${ }^{7}$ Aubry was a French sociologist whose works on anthropology, history, and geography are well know. He spent the last forty years of his life in Chiapas, as director of the archive attached to the Cathedral of San Cristóbal de Las Casas. He was also active with indigenous social causes.
} 
which was part of my findings in San Cristóbal. Although a monumental work with almost five hundred folios divided between soloists, choir, orchestra, and organ, the composer's name then had no meaning at all to me. Apart from transcribing this manuscript, I only had to research Gómez's life and works. Little did I know that I had begun research on the most active and prolific nineteenth-century Mexican musician. ${ }^{8}$ This research on Gómez not only formed the basis for my dissertation, but it also emphasized the need for cataloguing these manuscripts and provided the impetus for the first of my two main cataloguing projects.

The name José Antonio Gómez y Olguín did indeed appear in the music literature, mentioned by both local and foreign authors. The literature, however, paid scant attention to his music corpus and achievements or to any of his colleagues.

Figure 1: A general view of the Archivo Histórico Diocesano San Cristóbal de Las Casas (AHDSC) in Chiapas.

Photograph taken by the author (2015).

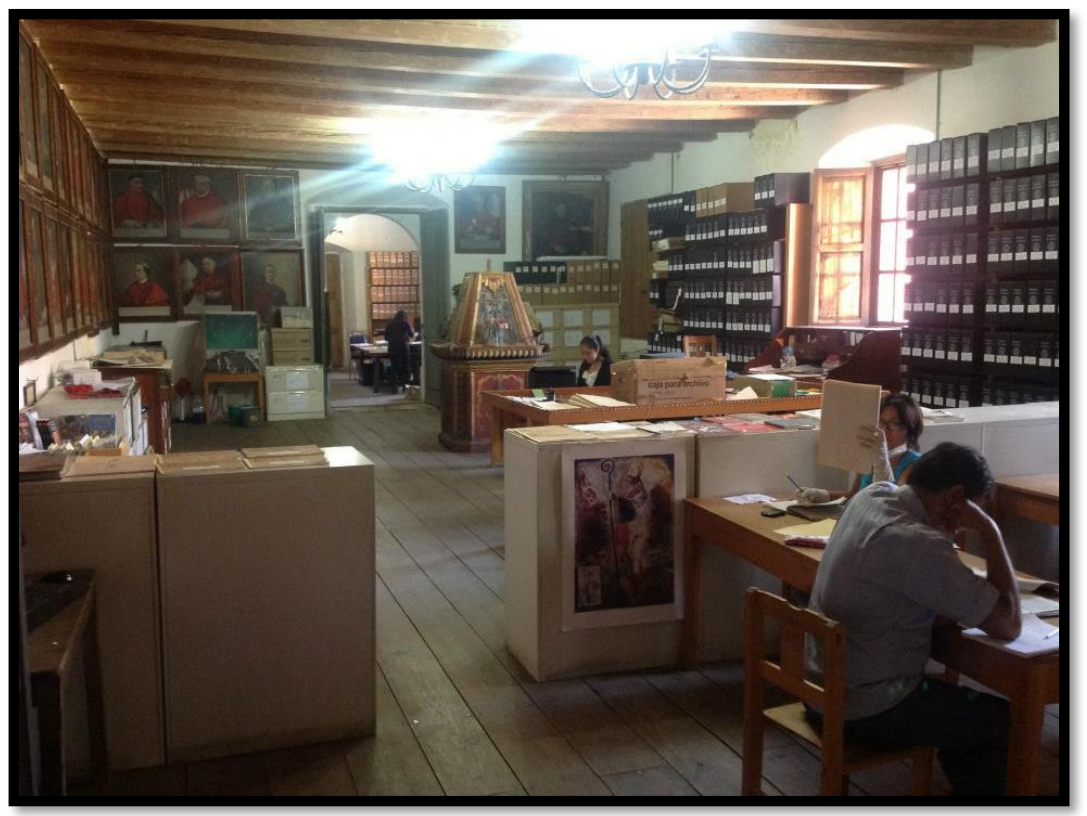

To paint a picture of this composer, I will present some highlights from his career. Between 1820 and 1865, Gómez served as organist, composer, and orchestra director at the main church in Mexico, the Mexico City Cathedral (MCC), the epicentre of matters religious, political, and social in

\footnotetext{
8 John G. Lazos, “José Antonio Gómez's Ynvitatorio, Himno y 8 Responsorios: Historical Context and Music Analysis of a Manuscript" (PhD diss., Université de Montréal, 2009). See https://papyrus.bib.umontreal.ca/xmlui/handle/1866/4676.
} 
the nineteenth century. He began as a soloist in the choir, and as a teenager, before Mexico became independent, he was already serving as third organist. Then his musical talents catapulted him into the position of first organist in 1835. This posting replaced the main duties of the chapel master position, which had just been dissolved. Gómez set out to explore the secular music scene, pioneering with multiple musical endeavours. After more than four decades of continuous service, he abruptly resigned his position at the MCC and moved to a modest, newly consecrated cathedral in Tulancingo, Hidalgo, one hour north of Mexico City. This is where Gómez spent the last eleven years of his life. Surprisingly, before my investigations, he was mainly remembered as the most senior member of the music committee that chose the score for Mexico's National Anthem.

To better understand the music of Gómez, my attention focussed on nineteenth-century Mexican music, and given the influence of Italian opera, on music that transitioned between sacred and secular settings. The first step was to read the extant music literature. ${ }^{9}$ Though relatively little had been written, there were common themes: an absence of original sources and a lack of scrutiny of the actual sounds of the music from the first decades of the Mexican nation. It seems that the music and musicians from the independent period were an undervalued part of Mexico's cultural heritage. An esteemed colleague had already noted that "either the music from this period [the nineteenth century] has escaped the eyes of the performers and the musicologists, or the sources have with time disappeared." ${ }^{10}$ Indeed, for a long time nineteenth-century music in Mexico had been neglected due to the prejudices created by the ideology of the twentieth century. Consequently, there had not been much interest in researching the music and musicians from independent Mexico. Recent research in the music from this period has now created a shift in attitude and a new appreciation for the original sources. We are gradually reclaiming a silenced past.

It seemed paradoxical that during my doctoral studies, while I was miles away from the relevant primary sources and not able to consult them in their archives of origin, I was able to freely consult

\footnotetext{
${ }^{9}$ Without making an exhaustive list, we can find references to José Antonio Gómez y Olguín in: Francisco Sosa, Bibliografías de mexicanos distinguidos, México (Oficina Tipográfica de la Secretaria de Fomento, 1884): 414-417; Miguel Galindo, Nociones de historia de la música mejicana (México, Colima, Tipografía de “El Dragon”, 1933): 504506; Jesús C. Romero, José Mariano Elízaga (México, Ediciones del Palacio de Bellas Artes, 1934): 141-146; Gerónimo Baqueiro Foster, Historia de la música III. La música del periodo independiente (México, SEP, INBA, 1964) 121-122; Guillermo Orta Velázquez, Breve historia de la música en México (México, Librería de Manuel Porrúa, 1971): 268-270; Hugo de Grial, Músicos mexicanos (México, Editorial Diana, 5a reimp., 1973): 11-12; Francisco Moncada García, Pequeñas biografías de grandes músicos mexicanos (México, Ediciones Framong, 2 ed., 1979): 109-111; Carlos A. Flores, Music Theory in Mexico from 1776 to 1866: A Study of Four Treatises by Native Authors (Ph.D. diss., North Texas State University, 1986): 134-135; Gabriel Saldívar, Bibliografía de musicología y musicografía (México, CENIDIM, 1991): 143-144; Lidia Guerberof Hahn, Archivo musical: catálogo (México, Insigne y Nacional Basílica de Guadalupe, 2006): 15; Gabriel Pareyón, Diccionario Enciclopédico de Música en México (2 vols., Zapopan, Jalisco, Universidad Panamericana, 2007): 435-437; Consuelo Carredano, Historia de la música en España e Hispanoamérica (vol. 6, Madrid, Fondo de Cultura Económica, 2010): 132.

${ }^{10}$ Ricardo Miranda, “Reflexiones sobre el clasicismo en México (1770-1840)," Heterofonía 116-117 (1997): 39.
} 
many related primary source documents on microform through interlibrary loan. Many of these facsimiles came from American universities. This process of facsimile consultation reinforced my commitment to helping other scholars and students connect with primary source documents for research and study and to understand these documents as sources of epistemological concern. In Canada, we believe it is our right, as researchers, to consult such sources. In Mexico, one must generally ask for permission to be granted this privilege.

The modest music collection at the Cathedral of San Cristóbal de Las Casas provided my first experience cataloguing music. It did not pose much difficulty, as its eleven manuscripts by five Mexican composers, including Gómez's Invitatorio, were complete and in perfect condition. It was when I visited the Cathedral at Tulancingo that I realized I had to take cataloguing seriously. ${ }^{11}$ Here, as in many religious archives, there was not even an inventory to indicate where the manuscripts might be found. As the reader is aware, the task of cataloguing takes time to complete, requires close coordination among colleagues, and a consistent working method. This was my initial work at Tulancingo.

It was at this time that I contacted RISM (International Inventory of Musical Sources = Répertoire International des Sources Musicales). ${ }^{12}$ On the one hand, I needed guidance for the requirements and formatting of cataloguing, and on the other hand, I wanted to make the sources, and the information they convey, available to a broader audience. What is the purpose of producing a music catalogue if it is not available for consultation? Yet this does happen!

There is no need to emphasize the long-standing importance of RISM in the western world of music sources, cataloguing, and research. When I began collaborating with them just a few years ago, their database had only 48 entries, from a single archive, representing Mexico. Clearly, this was a poor reflection of Mexican musical sources and music practice. At present, the number has surpassed one thousand works. These include some partial and some complete entries from eleven different archives. Again, this number is a small fraction of the actual number of music sources presumably dispersed throughout the country. Table 1 offers a view of the music now catalogued and awaiting further consideration through study and performance.

\footnotetext{
${ }^{11}$ It was Apoyo al Desarrollo de Archivos y Bibliotecas de México (ADABI) who financed this project. See https://www.adabi.org.mx.

${ }^{12}$ My contact since then has been Jennifer Ward, who has traveled to Latin America to give workshops on how to do cataloguing with RISM. See http://www.rism.info/fileadmin/content/communitycontent/Zentralredaktion/Ward RISM in Latin_America_Morelia for web.pdf.
} 
Table 1: An overall representation of the Mexican music entries found in RISM's database.

Note: The "*" symbol means that this archive has been partially catalogued. The number between parenthesis in the "Number of entries" column means that someone else, apart from me, is responsible for the cataloguing.

\begin{tabular}{|c|c|c|c|c|}
\hline & $\begin{array}{l}\text { Archive siglum, } \\
\text { Location, and } \\
\text { (type of place) }\end{array}$ & $\begin{array}{l}\text { No. of } \\
\text { entries }\end{array}$ & Main music genres & Main composers \\
\hline 1 & $\begin{array}{l}\text { MEX-Mc } \\
\text { Catedral Ma de } \\
\text { Mexico, Mexico } \\
\text { City (Cathedral) }\end{array}$ & $\begin{array}{c}66^{*}+ \\
(48)\end{array}$ & $\begin{array}{l}\text { Masses (36), Responsories (22), } \\
\text { Hymns (19), Invitatories (9), Sacred } \\
\text { songs (8), Passions (7), Graduals (4), } \\
\text { Motets (4), Requiems (4), }\end{array}$ & $\begin{array}{l}\text { Gómez y Olguín, José Antonio (65), } \\
\text { Juanas, Antonio de (37), Jerusalem, } \\
\text { Ignacio (3), Torres y Martínez Bravo, } \\
\text { José de (2), etc. }\end{array}$ \\
\hline 2 & $\begin{array}{l}\text { MEX-SCah } \\
\text { San Cristóbal de } \\
\text { Las Casas, Chiapas } \\
\text { (Cathedral) }\end{array}$ & 13 & $\begin{array}{l}\text { Psalms (4), Masses (3), Hymns (2), } \\
\text { Responsories (2), Instrumental } \\
\text { verses (2), Invitatories (1) }\end{array}$ & $\begin{array}{l}\text { Balcázar, Cruz (2), Gómez y Olguín, } \\
\text { José Antonio (2), Días de Herrera, } \\
\text { Santiago (2), }{ }^{13} \text { Luna y Monte de Oca, } \\
\text { Joaquín (2), Ortiz y Zárate, Ignacio (2) }\end{array}$ \\
\hline 3 & $\begin{array}{l}\text { MEX-Tahc } \\
\text { Tulancingo, } \\
\text { Hidalgo (Cathedral) }\end{array}$ & 176 & $\begin{array}{l}\text { Masses (54), Hymns (29), Sacred } \\
\text { songs (26), Psalm (15), Antiphons } \\
\text { (13), Instrumental verses (8), } \\
\text { Invitatories (6), Graduals (4), } \\
\text { Responsories (4) }\end{array}$ & $\begin{array}{l}\text { Anonymous (88), Gómez y Olguín, } \\
\text { José Antonio (26), Asioli, Bonifacio } \\
\text { (12), Valle, Antonio (5), Mercadante, } \\
\text { Saverio (4), etc. }\end{array}$ \\
\hline 4 & $\begin{array}{l}\text { MEX-SCSamp } \\
\text { San Cristóbal } \\
\text { Suchixtlahuaca, } \\
\text { Oaxaca } \\
\text { (Parish) }\end{array}$ & 87 & $\begin{array}{l}\text { Masses (35), Invitatories (7), } \\
\text { Overtures (7), Antiphons (5), } \\
\text { Hymns (5), Psalms (5), } \\
\text { Responsories (4), Sequences (4), } \\
\text { Villancicos (4), }\end{array}$ & $\begin{array}{l}\text { Anonymous (57), Lutrilla, Juan (5), } \\
\text { Arenzana, Manuel (4), Ramirez, } \\
\text { Salvador (4), Zuares, Hilario (3), etc. }\end{array}$ \\
\hline 5 & $\begin{array}{l}\text { MEX-SCHamp } \\
\text { Santiago } \\
\text { Chazumba, Oaxaca } \\
\text { (Parish) }\end{array}$ & 127 & $\begin{array}{l}\text { Masses (36), Sacred songs (19). } \\
\text { Invitatories (17), Hymns (12), } \\
\text { Responsories (10), Instrumental } \\
\text { verses (10), Symphonies (5), } \\
\text { Vespers (4) }\end{array}$ & $\begin{array}{l}\text { Anonymous (87), Rossini, Gioachino } \\
\text { (3), Arenzana, Manuel (2), Battmann, } \\
\text { Jacuqes-Louis (2), López, A. (2), Valle, } \\
\text { Antonio (2), Asioli, Bonifacio (1), } \\
\text { Haydn, Joseph (1), etc. }\end{array}$ \\
\hline 6 & $\begin{array}{l}\text { MEX-Mcnm } \\
\text { Consevatorio } \\
\text { Nacional de } \\
\text { Música, Mexico } \\
\text { City } \\
\text { (Conservatory) }\end{array}$ & $12 *$ & $\begin{array}{l}\text { Masses (8), Hymns (1), Marian } \\
\text { songs (1), Responsories (1), } \\
\text { Instrumental verses (1) }\end{array}$ & $\begin{array}{l}\text { Gómez y Olguín, José Antonio (11), } \\
\text { Luna y Montes de Oca, Joaquín (1) }\end{array}$ \\
\hline 7 & $\begin{array}{l}\text { MEX-Mahbg } \\
\text { Basílica de } \\
\text { Guadalupe, Mexico } \\
\text { City } \\
\text { (Basilica) }\end{array}$ & $11^{*}$ & $\begin{array}{l}\text { Masses (3), Psalms (2), Antiphons } \\
\text { (1), Canticles (1), Hymns (1), } \\
\text { Passions (1), Responsories (1), } \\
\text { Sacred songs (1) }\end{array}$ & Gómez y Olguín, José Antonio (11) \\
\hline
\end{tabular}

${ }^{13}$ Karen Elizabeth Benner (Karen Zacy Benner) completed her PhD dissertation at Concordia University based on the two manuscripts by Santiago Diaz de Herrera housed in San Cristóbal de Las Casas, https://spectrum.library.concordia.ca/980982/1/Benner PhD S2016.pdf 


\begin{tabular}{|c|c|c|c|c|}
\hline 8 & $\begin{array}{l}\text { MEX-Gcm } \\
\text { Catedral } \\
\text { Metropolitana de } \\
\text { Guadalajara, Jalisco } \\
\text { (Cathedral) }\end{array}$ & $4^{*}$ & $\begin{array}{l}\text { Sacred songs (2), Masses (1), } \\
\text { Responsories (1) }\end{array}$ & Gómez y Olguín, José Antonio (6) \\
\hline 9 & $\begin{array}{l}\text { MEX-SQamc } \\
\text { Conservatorio de } \\
\text { Música, Querétaro } \\
\text { (Conservatory) }\end{array}$ & 6* & Masses (5), Responsories (1) & Gómez y Olguín, José Antonio (6) \\
\hline 10 & $\begin{array}{l}\text { MEX-Oc } \\
\text { Arquidiócesis de } \\
\text { Antequerra, } \\
\text { Oaxaca } \\
\text { (Archdiocese) }\end{array}$ & $\left(15^{*}\right)$ & $\begin{array}{l}\text { Villancicos (11), Cantatas (3), Arias } \\
\text { (1) }\end{array}$ & $\begin{array}{l}\text { Sumaya, Manuel de (12), Salazar, } \\
\text { Antonio de (2), Anonymous (1) }\end{array}$ \\
\hline 11 & $\begin{array}{l}\text { MEX-Mahn } \\
\text { Colegio de } \\
\text { Vizcaínas } \\
\text { (College) }\end{array}$ & 443 & $\begin{array}{l}\text { Sacred songs (92), Masses (86), } \\
\text { Hymns (48), Responsories (31), } \\
\text { Overtures (30), Marian songs (29), } \\
\text { Antiphons (26), Psalms (21), } \\
\text { Graduals (11), Instrumental music } \\
\text { (8), Canticlers (7), Zortzikos (7), } \\
\text { Sequences (6), Villancicos (6), etc. }\end{array}$ & $\begin{array}{l}\text { Anonymous (158), Valle, Antonio } \\
\text { (34), Bustamante, José María (16), } \\
\text { Gómez y Olguín, José Antonio (15), } \\
\text { Centroni, Luis (12), Camacho, José } \\
\text { Cornelio (6), Gutiérrez. Gerónimo (6), } \\
\text { Rossini, Gioachino (6), etc. }\end{array}$ \\
\hline
\end{tabular}

With more than 140 entries, one composer's name is dominant throughout these collections. Except for the three archives in Oaxaca, José Antonio Gómez y Olguín is the connecting thread. I can only speculate that most of the works in these archives, specifically the anonymous items, were copied from the main music centres, such as the MCC, to be performed elsewhere with their respective differences and performing contexts. In such cases, the people who copied the music likely did not consider that the name of the composer was a priority. Rather, each was catalogued or labelled according to its place within the liturgical service, such as mass, hymn, or responsory. To verify this would require a comparison of works in the main music centres with those in the smaller archives. This is another massive pending project.

After finishing the music catalogue at the Cathedral of Tulancingo, ${ }^{14}$ I received an unexpected invitation to tackle the collections in two parishes in the north of Oaxaca. ${ }^{15}$ I was not prepared for such a surprise. In the province of Oaxaca, it is said that when you turn a stone, a musician appears. In particular, band music with brass and percussion is strong in this area. The people are proud to make music, to dance, and to demonstrate their love for music at every opportunity. There is a long musical tradition that started in the late nineteenth century, and it does not show signs of slowing down. ${ }^{16}$

\footnotetext{
${ }^{14}$ See http://www.tulancingocultural.cc/historico/archivohistorico/musical/sepresento.htm

${ }^{15}$ I received the invitation from Dr. Sergio Navarrete, member of the Centro de Investigaciones y Estudios Superiores en Antropología Social (CIESAS) unidad Pacífico Sur.

${ }^{16}$ The Centro de Capacitación Musical y Desarrollo de la Cultura Mixe is an autonomous indigenous centre where music has been taught and performed for more than forty years (http://www.cecam.org.mx/inicio.html).
} 
The research of liturgical music, or rather music connected to the composers associated with the church, has been concentrated mostly in the urban centres. Rural areas have generally been neglected. Santiago de Chazumba, the Oaxaca parish where I spent most of my time, is a small town literally in the middle of nowhere, with no more than 4,500 inhabitants. I was alerted to a collection of music there by someone who had noticed that the organ needed major repairs, and "by the way, we just also found out that there was some old music inside a couple of drawers." I had only three weeks to come up with something productive. For extra help, I arrived with two assistants who had no formal training in music. We were met with piles of music tightly bound by twine. The music had been tied for so long, that the old twine had dried and sliced right through several manuscripts. The working method for placing these works in order was simple. We began by dividing the sacred from the secular music, then we covered the floor with different colours of post-it notes to separate music according to its genre. I concentrated on the sacred works, which we were able to catalogue.

One can only imagine that Santiago Chazumba had a simple way of life during the first part of the nineteenth century. And yet, at some point there was an interest in updating its music collection. The parish probably requested, from the Cathedral of Puebla, religious music that was in fashion. Shortly after viewing my catalogue records for this collection, staff at RISM commented:

And who would have thought that the reputation of Joseph Haydn's Nelson Mass reached all the way to Mexico in the second half of the eighteenth century? A copy of the mass in $D$ minor (Hob. XXII:11) is held today by the Archivo Musical de la Parroquia in Oaxaca, Mexico (MEX-SCHamp) Sa-Ms-01-39, RISM ID no. 120000416). ${ }^{17}$ This source was not known when the work appeared in the collected works of Haydn (Reihe XXIII, Band 3), which was published back in $1965 .^{18}$

Returning to my ongoing work on Gómez, at this point in my research and cataloguing career I had done extensive investigation into his life and seen most of his music corpus. I had concluded that he was one of the most active and prolific nineteenth-century Mexican musicians and I had found numerous original sources and documents to support my argument. Not only were his achievements neglected in music research, we had no idea how his music actually sounded. A music catalogue dedicated to Gómez might raise awareness of this composer and his music. To make the case stronger, I decided to include, besides all the requirements established by RISM, a visual representation of each work at the top of each entry. The idea was to have a clear and distinct representation for each manuscript. In addition, I wanted this catalogue to be available as an open and consultable source. The printed reference book, still typical for Mexican catalogues, had become, in my opinion, too costly for our present budgets and obsolete for our times. So, with a

\footnotetext{
17 See https://opac.rism.info/metaopac/search?View=rism\&id=120000416.

${ }^{18}$ See http://www.rism.info/en/home/newsdetails/browse/8/select/self representation/article/64/results-ofthe-rism-user-study-part-iv-your-comments-libraries-coverage-and-completeness.html.
} 
Spanish and English introduction, I chose to present Gómez's music catalogue in a pdf format, available online for no cost. ${ }^{19}$ In addition to improved accessibility, the advantage of this format is that corrections and additions can easily be made.

I must now address the important foundational cataloguing of Mexican music that took place over four decades. Completed in 2002, it encompassed the entire music collections of two of the most dominant churches in Mexico, the Cathedrals of Mexico City and Puebla. They were the work of Thomas Stanford (1929-2018), who laboriously consulted microfilm collections, the images of which had been taken during the mid-1960s. Then with the assistance of Lincoln Bruce Spiess, Stanford worked on a small table in the middle of a compact room, since no one was permitted to move or remove any of the manuscripts from the MCC. Many years later Stanford still recalled that at the time "the archive was a huge messy pile." ${ }^{20}$ But most significantly, he stated in his introduction, "to the best of my knowledge, the music archives of the cathedrals of Mexico City and Puebla are the largest in the Spanish-speaking world; larger, even, that any of those in Spain itself."21 Until these works become accessible to researchers and performers, this archived music will sadly remain undiscovered, even for those who live close by in the city centres.

Here is one of the almost 80 entries for Gómez's works found in Stanford's catalogue. As we will see, this piece is of both musical and historical interest. On the top left, and below the roll number, we have two letters and a number, "B d 3," which is a topographic denomination indicating the placement of the document inside the closet when it was microfilmed by Stanford and Spiess. Nowadays these items are carefully placed inside boxes and well organized on shelves in a much bigger and more convenient room. Continuing with this entry, we have Gómez's full name, his dates (then incomplete, though now corrected), title of the work, instrumentation, location, number of pages, tonality, and contents, with number of pages for each part in parentheses.

\footnotetext{
19 John G. Lazos, “José Antonio Gómez y Olguín (1805-1876) y su Catálogo musical: Un acercamiento a la práctica musical del México decimonónico [English introduction included]," FONCA, (México, 2016, https://www.academia.edu/29078818/ Jos\%C3\%A9 Antonio G\%C3\%B3mez y Olgu\%C3\%ADn 18051876 y su Cat\%C3\%A1logo musical Un acercamiento a la pr\%C3\%A1ctica musical del M\%C3\%A9xico decim on\%C3\%B3nico English introduction included 2016.

${ }^{20}$ See https://archivo.eluniversal.com.mx/cultura/29021.html.

21 Stanford, Thomas. 2002. Catálogo de los acervos musicales de las catedrales metropolitanas de México y Puebla de la Biblioteca Nacional de Antropología e Historia y otras colecciones menores (INAH, México, D.F.) xvi.
} 
Figure 2: Fragment of Gómez's Te Deum entry as it appears in Stanford's Catalogue 22

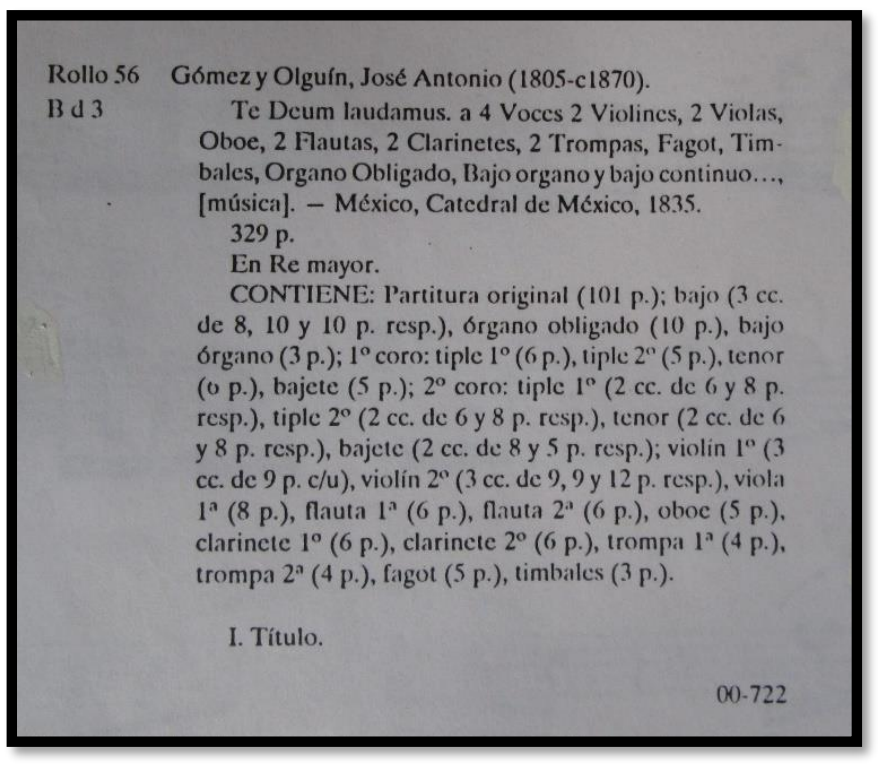

By the time of this composition, Gómez had just been chosen, "with all the votes" from the Chapel, as first organist at the MCC. ${ }^{23}$ He was at the top of the music chain when it came to independent Mexico, and he was only 30 years old. This particular work is noteworthy because Gómez was inspired by the political figure of the moment, General Antonio López de Santa Anna (1794-1876), called Generalísimo, meaning above all generals. Santa Anna also became president or vicepresident of Mexico on eleven separate occasions. In the historical accounts, Santa Anna represents the ancient regime, the conservative position of the time, the side that has taken most of the blame for what went wrong, a long list during this century, and for better or worse was the position with which Gómez was closely affiliated.

In 1835 Santa Anna gathered his army and went to the north to repress the rebels at the Battle of Zacatecas. ${ }^{24}$ Shortly after the battle, which lasted no more than two hours, the Chapel of the MCC honoured Santa Anna by inviting him to a solemn Te Deum followed by an exquisite drink. ${ }^{25}$ The newly appointed young organist seized the opportunity to show off his compositional talents and write, in what is a direct laudatory reference, his Te Deum Laudamus. Gómez commented that it

\footnotetext{
22 Stanford, Catálogo de los acervos, 121.

${ }^{23}$ Archivo del Cabildo Catedral Metropolitano de México (ACCMM). Actas Capitulares, Libro 73, Folio 273 r, 17 de julio de 1835 .

${ }^{24}$ See information on Santa Anna, and the Battle of Zacatecas, https://www.britannica.com/topic/TexasRevolution.

${ }^{25}$ ACCMM, Actas de cabildo, Libro 73, ff. 268r-268v, 13 de junio de 1835.
} 
took him only "two and a half days" to complete. ${ }^{26}$ Here is the entry for Gómez's work showing the cover and first page of the score as it appears in the catalogue that I produced: "José Antonio Gómez y Olguín (1805-1876) y su Catálogo musical: Un acercamiento a la práctica musical del México decimonónico" [English introduction included]", FONCA (México, 2016).

Figure 3: First page of Gómez's Te Deum entry taken from Gómez’s Music Catalogue ${ }^{27}$

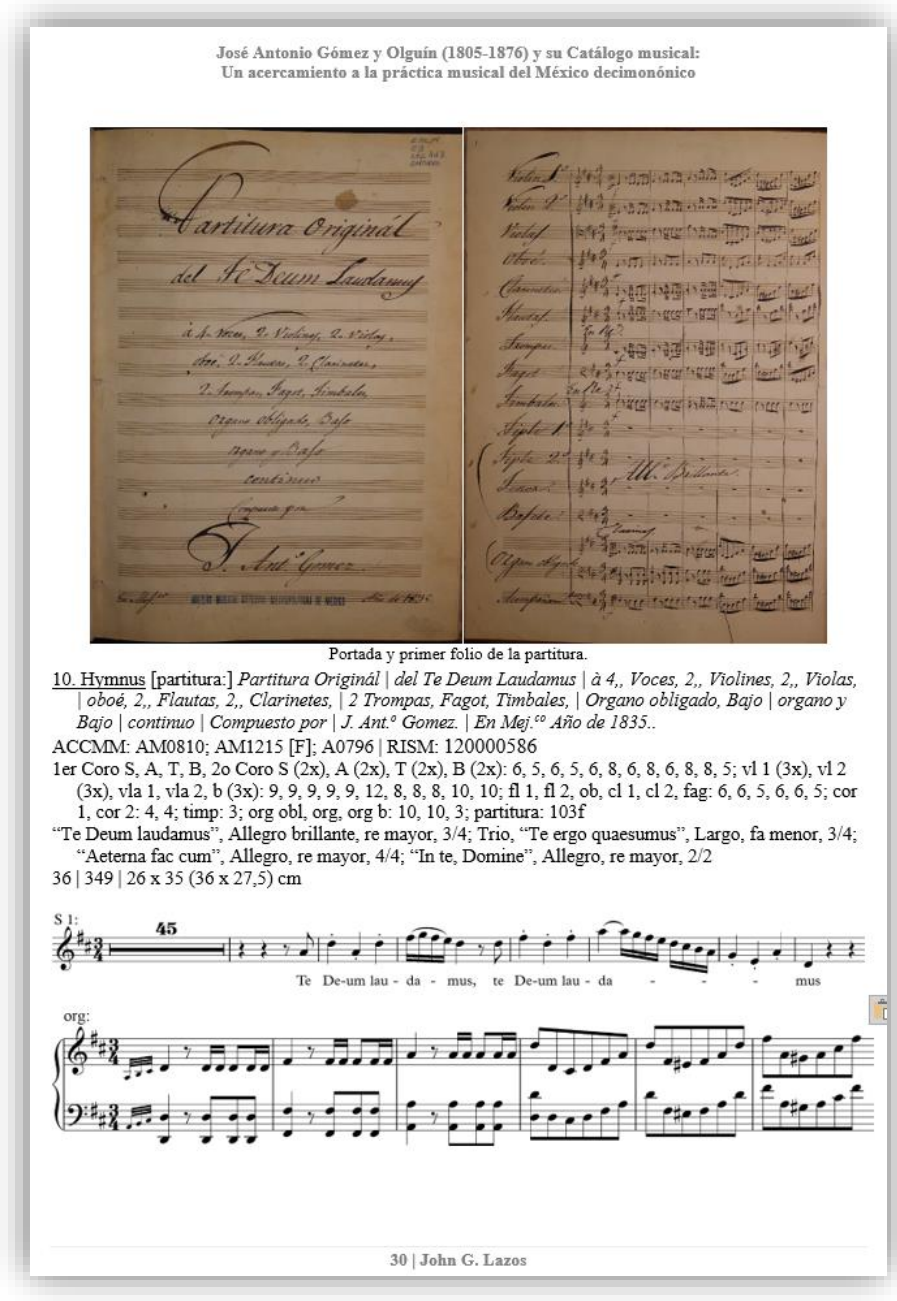

I have long noted how little the music of early nineteenth-century Mexico is performed or understood today, despite the importance of composers such as Gómez in the life of Mexico City. A clear example of this oversight occurred in 2010, the so-called year of the Bicentenario. This was the

\footnotetext{
${ }^{26}$ Galván Rivera ed., Calendario de las Señoritas Megicanas para el año bisiesto de 1840 (Dispuesto por Mariano Galván, México, 1840): 199.

${ }^{27}$ Lazos, “José Antonio Gómez y Olguín...," 39.
} 
ideological label that referred to the two hundred years since the Mexican Declaration, and not consummation, of Independence. The year-long celebration had its highpoint on the night of September $15^{\text {th }}$, which is recognized as the national holiday. There was no restraint to spending for this commemorative and popular moment at the Zócalo, the centre of the nation's capital. The MCC and the National Palace were the backdrop for the night's celebration, which reached its climax with special lighting, fireworks, and of course, music. The work that closed the night's celebrations, Sinfonia India by Carlos Chávez (1899-1978), was chosen to epitomize the sound of nationalism and what it means to be Mexican. Ironically, if not recognized at that moment, this celebration of nineteenth-century independence was best portrayed by the sounds of the twentieth century. It seems odd that one period of sounds can usurp another without any consideration for the original music of the period.

Towards the end of 2019, I had a two-month residency in Morelia, Michoacán, four hours west of Mexico City. ${ }^{28}$ For the first time, my project was moving from archival research to performing some of the works now catalogued. Morelia is a colonial-style city that regularly organizes musical and cultural festivals. Its music schools produce well trained musicians able to perform music from ancient to contemporary repertoire. My objective was modest. I proposed to transcribe and perform small works for voice and organ with some musicians from the city. For years prior, I had been trying, without success, to convince colleagues to perform nineteenth-century Mexican music. I thought that a few intimate works might draw some attention to the repertoire and the wealth of sources available for performance. Suddenly, I was sitting down with the conductor of the Orquesta Sinfónica de Michoacán, Román Revueltas, who had been the concertmaster of the orchestra I had belonged to years before, the Orchestra Filarmónica de Querétaro. Maestro Román liked my project and offered me 15 minutes at the orchestra's year-end concert to present a work of my choosing. I took this opportunity to prepare Gómez's Te Deum. Then I realized that I needed rather more than two and a half days to transcribe only its first section.

\footnotetext{
${ }^{28}$ I was the recipient of the 2019 Conseil de Arts et de Lettres du Québec (CALQ) exchange program : Échanges d'artistes et d'ateliers-résidences Québec-Mexico. See https://www.calq.gouv.qc.ca/wpcontent/uploads/2019/08/fiche-reci-mexique-web-en.pdf.
} 
Figure 4: The Orquesta Sinfónica de Michoacán, conducted by Román Revueltas during the performance of Gómez's Te Deum at the Ocampo Theater on December 18, 2019

Photograph taken from Facebook. ${ }^{29}$

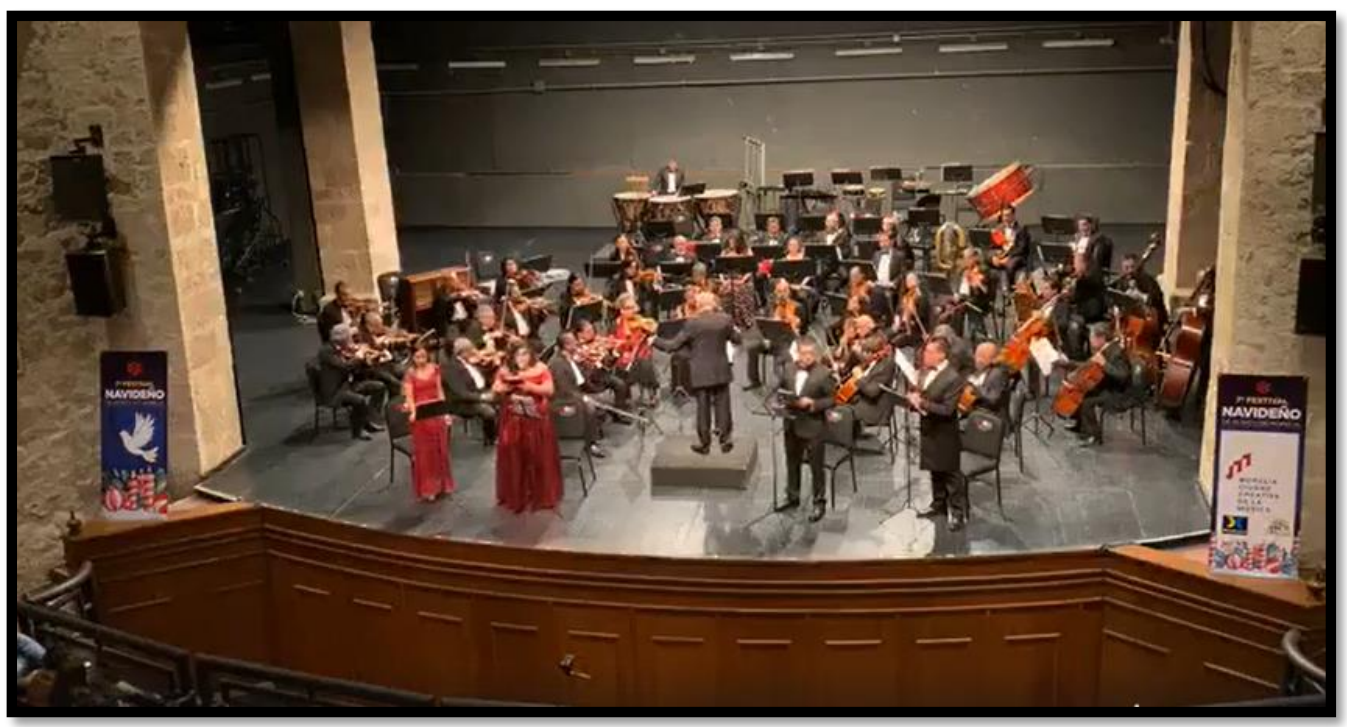

It is one thing to describe a manuscript using a standard set of categories for an overview of the physical document plus commentaries. It is another thing to try to understand the characteristics of a musical work that has not been performed in almost two centuries. Given the unfamiliarity of this style of music, its orchestral texture, sound, and structure, Gómez's Te Deum did not at first meet our expectations. To begin with, it is not the typical sober piece that might be associated with the church. We know, however, that this work belonged to the actual practice of music in Mexico City during the first part of the nineteenth century. In the rush to transcribe the work for the performers I, like so many copyists before me, forgot to include the name of the composer! Since the musicians had no idea who they were performing (music from their own past), they were not hampered by any preconceptions, and most reacted favourable to the piece.

Gómez's Te Deum opens with an intense unison of instruments and voices that escalates throughout the chord of D Major in a martial and majestic motive. Then, the character shifts to a pastoral solo between the soprano and the first oboe; this is followed by the dark voice of the bass accompanied by an ostinato in the strings that echoes Mozart's Commendatore. The opening introduction briefly returns and leads to the flute and tenor solos with strings in pizzicato. The first

${ }^{29}$ See and listen to Gómez's Te Deum Laudamus, minutes 1 to 15. The soloists are: Luz A. Romero, soprano; Joselin F. Mendoza, mezzo; Alberto Sánchez, tenor; Pablo C. Reyes, bass; Laura Carrasco, organ. See https://www.facebook.com/orquesta.michoacan/videos/d41d8cd9/556020414975948. 
section closes with a solo for the organ and strings balancing the mezzo before returning to the main theme with the soloists for the dramatic and theatrical ending.

At this point in my research, I started to consider an expanded catalogue for all the works by Gómez. When I began working on Gómez's music corpus in 2015 , I was told there was music by him at the Archivo Musical del Colegio de Vizcaínas (AMCV). There are indeed 14 of his works there, with completely different repertoire from the MCC, although the buildings are separated by only $1.5 \mathrm{~km}$. Vizcainas was founded at the end of the eighteenth century by the Basque people of Mexico City. They were rich and wanted to invest their money in assets. They obtained a piece of land at the outskirts of the city where they built a massive two-storey rectangular building. As is typical for massive architecture from those times, the Colegio de Vizcainas has slowly been sinking into the ground. It is still in use, and inside its walls, time seems to stand still. It is the oldest educational edifice in continuous use as a school in Mexico City since 1767. When I first arrived at the AMCV, I found an exceptional situation: a normal and regular schedule, an ample room, tables to use for my research, and staff ready to assist. They only lacked a proper music catalogue, which inspired the second of my main cataloguing projects.

Figure 5: Fragment from the Music Section of the AMCV created by Mónica Salazar The entry represents one of Gómez's works, though his first name should be José and not Juan. ${ }^{30}$

Fondo Sección de Música

Onomástico Gómez y Olguín, Juan Antonio.

Contenido Invitatorio a duo y órgano por Juan Antonio Gómez y Olguín.

Temático Música

Lugar Ciudad de México

Much of the repertoire included in this collection is musically rich and technically demanding. The original students, the schoolgirls as they were commonly called, had in their daily routine a series of activities and studies which included the practice and study of liturgy, the Mass, and Divine Office. Naturally, music was an integral part of these studies. While most of the musical texts are religious and in Latin, there are also some examples of vocal music in Spanish and in Basque. As well, this

${ }^{30}$ Mónica Salazar López. Guía general del Archivo Histórico "José María Basagoiti Noriega". (Document in pdf format, México, N/D): 36. 
music collection includes music methods, instrumental studies, overtures, sonatas, and even a collection of dances known as zorcicos. ${ }^{31}$

The AMCV, like many archives in Mexico, came to public attention in the 1960s. The following notice, from the newspaper El Excelsior, focusses on an important musical event: the performance of a work by a Venetian composer, Giacomo Facco, which had been recently discovered at Vizcainas. ${ }^{32}$ What should be additionally noted is the brief, offhand mention of where the Facco score was located, as it seems that from a researcher's perspective this is more memorable than the concert night itself. Pay attention to the adjective used to describe the archive.

Last night the "Orozco and Berra" hall at the Castle of Chapultepec saw the premiere of a newly discovered work by the Venetian composer Giacomo Facco, who passed away 206 years ago [in 1753]. The director, Uberto Zanolli, conducted twenty-five performers and also organized the music manuscripts found in a dusty archive at the College of Vizcainas. ${ }^{33}$

That dusty archive is no other than the AMCV that is now part, among other collections, of the Archivo Histórico "José María Basagoiti Noriega" del Colegio de San Ignacio de Loyola Vizcaínas. The catalogue of the AMCV sheds light on the links between the musical world of women's education, women in society, liturgical practices, daily life, pedagogy, the arts, politics, and even economic factors connected to the history of the music contained within these walls.

The sonorous world of this archive dates back to the sixteenth century, from the early period of New Spain, when a Franciscan missionary established a house to welcome the mestizas, girls born from the "love of the Spanish conquerors with the indigenous women." ${ }^{34}$ During the next century, as a result of a needed female population, an Austrian priest founded another similar institution, the Recogimiento de San Miguel de Belén, just metres away from the current College of Vizcainas, which was committed to taking in adult women who were living on the streets. Then in 1548 , an additional college for women, the Colegio de Niñas de Nuestra Señora de Caridad, was founded. It was not until 1737, thanks to the fraternity of Aránzazu, the Basques who lived in Mexico City, whose interest was to house widows and orphaned girls in despair, that the Real Colegio de San Ignacio de Loyola was established.

During the second part of the nineteenth century, the Reform Laws were enacted and the assets belonging to the church were appropriated by the State. Shortly after, the first two religious

\footnotetext{
${ }^{31}$ See https://www.mexicanist.com/l/music-of-six-basque-zortzikos-of-the-xix-century-thought-to-be-lostfound-in-mexico/

32 See Uberto Zanolli, Giacomo Facco. Maestro de Reyes (Editorial don Bosco, México, 1965).

${ }^{33}$ El Excelsior (México), July 12, 1962.

${ }^{34}$ Ana Rita Valero de García Lascuráin, El Tesoro de Vizcaínas: sus documentos antiguos, memoria del mundo (ADABI, México, 2014): 19.
} 
institutions for women, Caridad and Belén, had to close their doors. The third institution, Vizcaínas, had a different destiny. Because it had secular origins, first named after San Ignacio de Loyola, later as Colegio de la Paz, and today as Colegio de Vizcainas, it survived the dissolution of the ecclesiastical properties and it was also enriched by incorporating the collections of the two former colleges into its own. This is the music corpus that we now have at hand.

A music collection of this magnitude and historical significance demands a catalogue. Fortunately, the archive had recently digitized its collection of more than 20,000 images. I just needed to create a database, a draft first version with more than 600 entries, and make an in-situ review to ensure that the order of the original manuscripts and printed music was correct. This was not always the case. I also verified that the images followed the original scores. This parallels the principle suggested by Joseph Kosuth in his conceptual work One and three chairs (1965): an actual chair flanked by a photograph of the chair and a dictionary definition. An object, or in the case of music cataloguing a score, is represented in three parts. This is what I wanted my music catalogue to resemble. ${ }^{35}$

I chose an oblong format to make it easier to consult, and apart from the Spanish and English introductions, I included indices for composers, music genres, and literary incipits. The AMCV catalogue consists of almost 400 manuscript entries and 162 printed scores. The catalogue is also available through the college's website. ${ }^{36}$

Gómez's works in Vizcainas contrast vividly with those by him at the MCC. While the latter are scored for soloists, choir, a full orchestra, and organ--the main instrument of the composer-the works housed at the former archive are of a more intimate and private nature. We can imagine that the girls at Vizcaínas, though they had music training, were not expected to be professionals.

Besides, their liturgical services were not open to the public as they were at the MCC. The musicians pictured in Figure 7 are performing Invitatorio-Himno, a short, easy to memorize work in two parts, which plays around two female voices accompanied by the organ. Such a piece, that would have opened the long service of Matins, captures the freshness and simplicity of this repertoire.

${ }^{35}$ One and three chairs (1965) by Joseph Kosuth, https://www.moma.org/collection/works/81435 and https://www.moma.org/learn/moma learning/joseph-kosuth-one-and-three-chairs-1965/.

36 "Catálogo de Música” in https://colegiovizcainas.edu.mx/archivo. 
Figure 6: The entry for Gómez's Invitatorio-Himno as it appears in Catálogo del Acervo Musical del Colegio de Vizcaínas (AMCV)

La memoria sonora de los colegios femeninos en México entre los siglos XVI-XIX (The sonorous memory of the women's colleges in Mexico between the sixteenth and nineteenth centuries). ${ }^{37}$

CATÁLOGO DEL ACERVO MUSICAL DEL COLEGIO DE VIZCAÍNAS (AMCV)

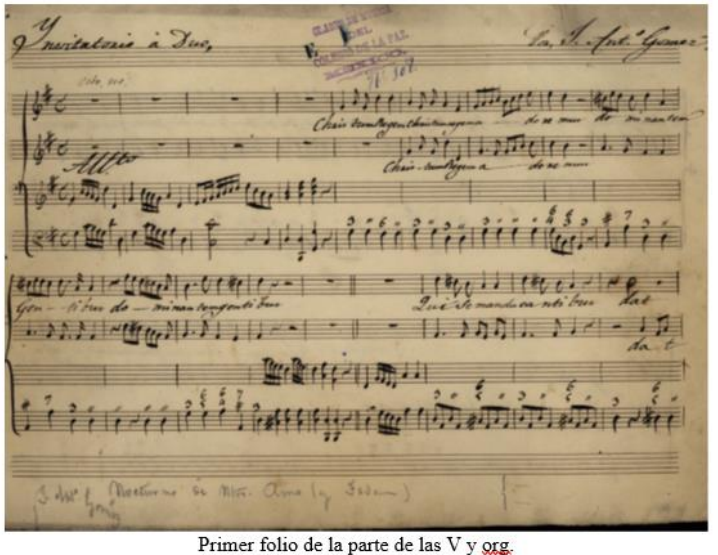

291. Invitatorio-HImno: [V 1-2 y org:] Ynvitatorio á Duo, Por, J. Ant.o Gomez. Gómez y Olguín, José Antonio

V 1-2 y org: $4 \mathrm{f}$

Invitatorio "Christum Regem", Allegretto, Sol M, 4/4; Himno "Sacris solemnis juncta", Andante, Re M, 3/4

$1|4| 34 \times 24$

E26-TII-C2-L45 | 120000520

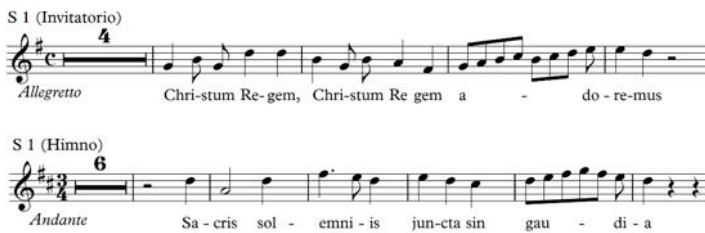

A lápiz en la parte inferior del primer folio dice: "J. Ant.o Gomez Nocturno de Ntro. Amo (y Tedeum)".

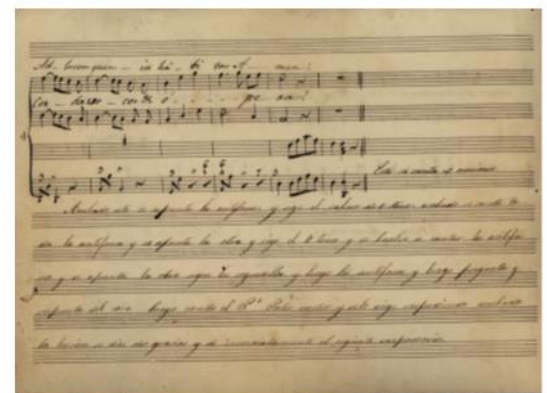

En el último folio dice: "Este se canta 4 ocasiones $\mid$ Acabado esto se apunta la antifona y sige el salmo de 5 tono. acabado se canta to- $\mid$ da la antifona y se apunta la otra y sige el 6 tono y se buelbe a cantar la antifo- | na y se apunta la otra sigen las seguidillas, y luego la antifona y luego pregunta y $\mid$ respuesta el coro. luego canta el

P. Pater noster y sele sige respondiendo acabada | la lecssion se dise deo gratia inmediatamente el siguiente responsorio."

Sello del Colegio de la Paz: "E, No. 308".

${ }^{37}$ Both music catalogues, Gómez and Colegio de Vizcaínas, were possible thanks to the support received by the FONCA within the Programa de Fomento a Proyectos y Coinversiones Culturales in Mexico. 
Figure 7: Gómez's Invitatorio-Himno performed by the Dueto Monteverdi, Alejandra Zavala, soprano; Regina García, mezzosoprano; and Laura A. Carrasco organ

Photograph taken from Facebook. ${ }^{38}$

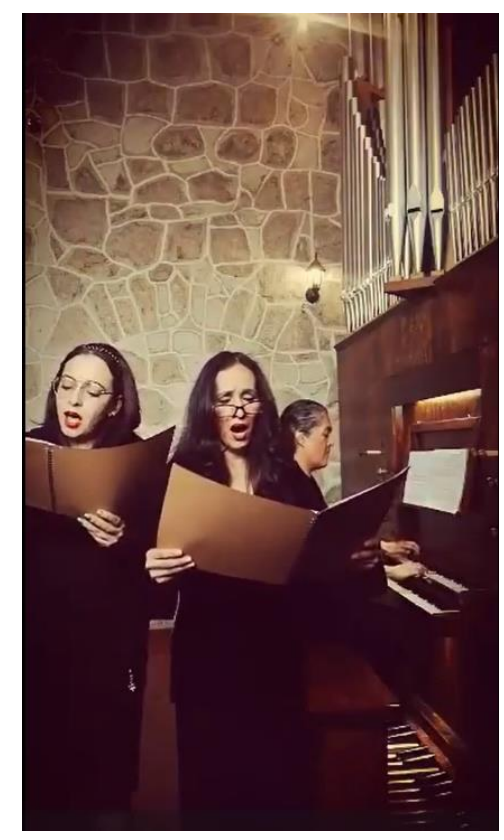

My next and current cataloguing project took me to the city of Querétaro, a stronghold of the nineteenth-century independence movement. It is located two hours north of Mexico City and has its own music conservatory. Founded at the end of the nineteenth century as a sacred music school, known now as the Conservatorio de Música "José Guadalupe Velázquez," from its founding it followed the principle that music had to be taught and performed according to the traditional liturgical forms. In this way, it was prepared for the Motu Proprio issued by Pope Pious X in 1903, which condemned all theatrical musical expression which had been part of church liturgy during the nineteenth century. ${ }^{39}$ However, this conservatory was also well known for a room that had for decades collected music from convents, churches, local and foreign composers, donations, etc. Evidently, no one had been able to enter this room for many years.

In 2019, the room was renamed Archivo Histórico Mtro.Agustín González de la Escuela Diocesana de Música Sacra y Conservatorio de Música "José Guadalupe Velázquez (AHMAG). It has more than 12,000 documents according to the four-volume inventory created by its first and only custodian,

\footnotetext{
38 See https://www.facebook.com/Monteverdidueto/videos/3832559150103563/.

${ }^{39}$ See Pio X. Carta Pastoral Colectiva de algunos prelados mexicanos, con el motivo del documento Pontificio expedido motu Proprio. Por Ntro. Smo. Padre el Sr. Pío X acerca de la música sagrada (Imprenta Guadalupana de Reyes Velasco, México, 1904).
} 
David Saavedra. I was stunned by the number of documents stacked from floor to ceiling against the walls and on the tables of this dark and almost claustrophobic room that Saavedra had been keeping for more than four decades. It is a dormant corpus of eclectic documents. I thought, if this collection could be organized and catalogued, the students and professors of the school, as well as anyone interested, could benefit from the history and memory that the conservatory has to offer. Fortunately, the director understood and decided it was time to properly organize the massive array of documents and create a normal music catalogue. And so, a new music project has begun.

Figure 8: Cataloguing team that has been working at the Music Conservatory in Querétaro.

From left to right, John G. Lazos, Jazmin M. Villalobos, Mariana Iniesta, and Jorge Vargas (December 2019). ${ }^{40}$

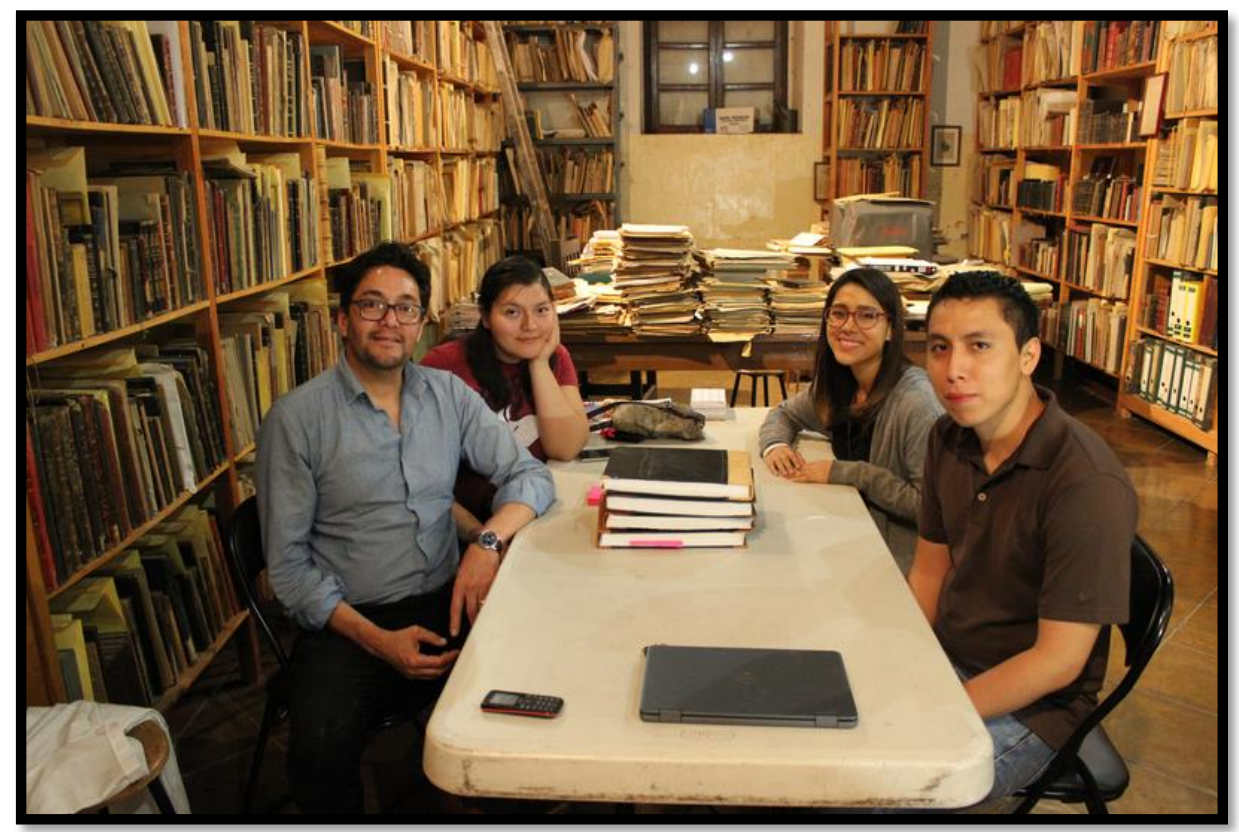

\section{Conclusions}

This account, purposely anecdotal, illustrates how the research of one work, Gómez's Invitatorio found in San Cristóbal de Las Casas, has generated over the years a palette of investigative themes of research and cataloguing. ${ }^{41}$ For the past fifteen years and still counting, I have been travelling all

\footnotetext{
${ }^{40}$ See http://www.rism.info/de/startseite/newsdetails/article/2/new-rism-cataloging-project-at-theconservatory-of-queretaro-mexico.html.

${ }^{41}$ The following are some recent academic works that concern nineteenth-century Mexican music and include the name of Gómez: Alejandra Hernández Sánchez, José María Bustamante en la capilla de música de la Catedral
} 
around Mexico from archive to archive, asking permission to see music manuscripts. While in some of the places where Mexican music is archived there is still resistance to consulting even a single document, work becomes possible when manuscripts, names of composers, the titles of works, and the extent of collections become known. I am convinced that a concerted collective participation, including researchers, archival staff and students, will change the archiving procedures and make sources accessible. This process of gaining access to a collection, whether it be in a cathedral archive or a conservatory, takes some diplomatic skill and patience. It also requires a basic amount of funding. With more public and private institutional support, so many more music archives could be catalogued.

The work described here and in catalogues by other researchers of nineteenth-century Mexican music has helped change perceptions of a whole period of music that had previously been abandoned. Clearly, the awareness of original sources has created an interest, both from outside and from within Mexico. That is why my last two completed music catalogues place an emphasis on identity and uniqueness through a visual representation of each work. It is a deliberate invitation to consult and study the sonorous memory of Mexico. I have been asked more than once why the many thousands of manuscripts and documents in music archives scattered around the country are still not accessible. It does not make any sense in our present time, when manuscripts can be available online, to make it complicated to see them in a public institution. The answer is patience and proper cataloguing.

The practice of keeping music manuscripts inaccessible goes back to the oral tradition and the expectation that researchers and musicians would travel to archives and speak directly with the people in charge. One must balance the risks of handling the documents against the considerable benefits of having them organized and known. Once the documents are catalogued and accessible, archivists gain the sense of pride of ownership, while researchers and musicians have opportunities for study and performance. I believe that all concerned will benefit greatly from a more open practice.

Metropolitana de México (BA thesis, UNAM, 2011); Luisa del Rosario Aguilar Ruiz, La imprenta musical profana en la Ciudad de México, 1826-1860 (MA thesis, UNAM, 2011); Yael Bitrán Goren, Musical Women and Identity-Building in Early Independent Mexico (1821-1854) (PhD diss., Royal Holloway, University of London, 2012); Laura A. Carrasco Curíntzita, José Antonio Gómez's Versos para órgano (Versets for organ) (Section I): A Practical Guide for Performance (DMA in organ, University of North Texas, College of Music, 2013); Rafael Enrique Salmerón Córdoba, El Cuaderno de Merced Acebal en el México decimonónico, (MA thesis, Universidad Veracruzana-Facultad de Música, 2016); Benner, Karen Elizabeth (2016) Somewhere Between Orthodoxy and Good Taste: Santiago Díaz de Herrera's Musical Settings of Psalms Dixit Dominus and Letatus Sum. (PhD diss., Concordia University, 2016); Alejandra Hernández Sánchez, La orquesta y la colección de obras reunidas por José Ignacio Triujeque: la introducción de una formación independiente en la práctica musical de la Catedral de México (1838-1850), (MA tesis, UNAM, 2017); and Luisa del Rosario Aguilar Ruiz, La imprenta musical profana en la Ciudad de México, 1860-1877 (PhD diss., UNAM, 2018). 
There is an understanding that the frequency with which a cultural institution is consulted, in situ or online, is in the same proportion to its importance and place within society. We are still waiting for the places and spaces that house important music documents in Mexico to follow in the steps of other cultural institutions and open their doors for consultation. Even if it takes time to make this decision, at least the creation of order for these documents through identification, digitalization, and music catalogues will bring awareness of the wealth of music documents that exist in Mexico. Since music is integral to human relations, access to music documents can help reshape ideas about the past.

I wish to take a moment to publicly thank all the people who have been involved in assisting, supporting, and following my music path and contributions. When all this began, fifteen years ago in the remote city of San Cristóbal, Gómez and his music were hardly mentioned in the literature. Evidently things have changed, and there is now significant interest in his work and other music from nineteenth-century Mexico. We have witnessed, for example, a significant increase in congresses scheduling entire sessions, scholars writing articles and theses, and musicians taking risks by performing this music. I have been only one voice in this chain of friends, students, and colleagues in Mexico and from many parts of the world. We share a common idea: the wish to access and study first-hand the long-overlooked music of Mexico. No one yet knows what the next fifteen years will bring to all of us, though I expect the work and the music to be fascinating. 